\title{
The Choir Stalls of St Martin in Emmerich: History of a Battered Ensemble
}

\section{Willy PIRON}

When entering St Martin in Emmerich, at the far end of the church, against the southern wall of the transept, one sees medieval choir stalls made by an unknown artist (Fig. I and Colour Plate IX, indicated in green). ${ }^{\mathrm{I}}$ It is clear that the present day location is not the original one. In I892 Paul Clemen saw the stalls in their original place in the choir and defined them as follows: 'Die Emmericher Chorgestühle sind die reichsten und ausgedehntesten ihrer Gattung am Niederrhein [...]'. ${ }^{2}$ Clemen did not know he was looking at a much-altered ensemble that was missing some of the original elements from I486. This paper will describe the crucial moments in the history of the ensemble and the substantial changes made to it. Missing elements will be reconstructed in order to come up with a proposal for what the choir stalls looked like in I486. We will move backwards from the present day. First the context of the choir stalls will be given by means of a short history of the church and its chapter. A biography of the patron of the choir stalls will be included in order to establish the influence he had in the design and whether there are recognizable marks of his patronage.

\section{The Church and Chapter of St Martin}

The vita of St Radboud of 9I4 mentions two presbyteres de coenobio Embricensi which means that by that time Emmerich already had a chapter or a monastery. ${ }^{3}$ Emmerich had been an archdeaconry of the diocese of Utrecht at least since the beginning of the twelfth century. In II3I it is documented that Bishop Andreas von Kuik of Utrecht was provost and archdeacon in Emmerich before his election as bishop. ${ }^{4}$ The Chapter of St Martin, together with the chapters of Deventer, Arnhem and Oldenzaal, formed the oldest chapter of the diocese of Utrecht. The deans of these four chapters in collaboration with the five chapters of the city of Utrecht chose the bishop of Utrecht.5 After the dissolution of the archbishopric of Utrecht during the Reformation, Emmerich became the most detached post of the so-called Hollandse Zending. From here the Catholics tried to govern and convert the Protestant parts of the Netherlands. The chapter existed till I8I I when Emmerich became part of France. Under French law all the convents and chapters were dissolved and St Martin became a parish church. ${ }^{6}$

According to legend, in 700 St Willibrord dedicated the oldest church in Emmerich to St Martin. This church was in the south of Emmerich. The Church and Chapter of St Martin were moved to the north of Emmerich at the beginning of the tenth century, after which the old church became the parish church St Aldegundis. In $c$. IO4O the new Church of St Martin was built by Bishop Bernold of Utrecht (I027-54). Its architecture was very similar to the other churches built by Bernold, such as the Church of St John in Utrecht and St Lebuinus in Deventer. The Church of St Martin was damaged badly in I 237 to I 238 when the Rhine washed away parts of the nave and the western block. From the church that had been built by Bernold only the crypt, choir, crossing, and most eastern bay remained. The church was renovated and enlarged in the fifteenth century, but because the Rhine was flowing directly west of the church, the northern transept was replaced by a double nave with a tower. An Eisbrecher or icebreaker, a big round tower to protect the church from the Rhine, was also built on the south west side of the church (Colour Plate IX, inset). ${ }^{7}$ Around 1485 the choir of St Martin was rebuilt radically in the Gothic style and a rood screen was erected. ${ }^{8}$ The church was almost completely destroyed in 1944 and a very plain rebuilding programme was completed in 
I966. A more thorough restoration took place from $1976-89 .{ }^{9}$

\section{The Patron of the Choir Stalls}

Shortly after 3 June I 483 an entry was made in the Calendarium anniversariorum of the Convent of St Martin: 'Anno domini $\mathrm{M}^{\circ} \operatorname{cccc}{ }^{\circ} 1 x x x i i j{ }^{\circ}$ obiit Venerabilis et Illustris dominus Mauricius comes deSpegelbergh capellarius et canonicus sancte ecclesie Coloniensis ac prepositus Embricencis archidiaconus ecclesie Trajectensis. Qui tempore vite sue dedit nova sedilia arteficiose et excquisite fabricate'. ${ }^{\text {Io }}$ The deceased was Count Moritz von Spiegelberg, born either at the end of I 406 or the beginning of I407 as the youngest child of the noble family Von Spiegelberg who were vassals of the bishop of Hildesheim. Their fief was situated between Hameln and Hildesheim, and Moritz was probably born there. ${ }^{\text {II }}$ His grandparents were members of the noble families of Spiegelberg, Hoya, Lippe and Wunstorp. ${ }^{\text {I2 }}$

As was often the case with younger sons of noble families, Moritz von Spiegelberg was destined for a career in the clergy. In I4I 8 his father succeeded in getting Moritz the post of abbot of Corvey when he was only eleven years old. He was not a priest nor a member of the Benedictine order which meant he was a secular lord of Corvey. ${ }^{13}$ In 1427 he was registered at the University of Leipzig. In I 434 his father was killed after a conflict with the dukes of Lüneburg, Braunschweig-Calenberg and BraunschweigWolfenbüttel (the Spiegelberg Feud) and Moritz von Spiegelberg was deposed as abbot of Corvey. ${ }^{\mathrm{I}}$ Already by $\mathrm{I} 435$ he had become a member of the most exclusive cathedral chapter of Germany, the Chapter of Cologne. ${ }^{\text {Is }}$ In the same year he also became a member of the council of Basel. His activities in I 436 and I437 are confirmed in the council's archives. ${ }^{16}$

In I443 Von Spiegelberg applied for a seat in the Chapter of Utrecht but failed. Not until I468 did he succeed in becoming a canon in Utrecht. In I444 the position of dean at the Chapter of St Martin in Emmerich became vacant when Peter van der Meer, who had been dean since I424, died. Von Spiegelberg became his successor in the same year. He also managed to get seats in the chapters of Trier (I46I) and of Maastricht (I466). Despite his appointments in many cities he lived in Cologne where he owned a house and where his presence is stated in the reports of the chapter meetings which he almost never missed. ${ }^{17}$ It was not until I 458 that Von Spiegelberg went to Emmerich for the first time, and in the I 460 s he spent more time there. A conflict in Cologne in I 474 forced him out of town and for two years he lived in exile in Emmerich, the only part of the duchy of Cleves that was not under the jurisdiction of the bishop of Cologne. ${ }^{18}$ On 3 June I483 Von Spiegelberg died in Cologne and was buried, in accordance with his own wishes, in front of the altar of St Anthony in the Cathedral of Cologne. Some time before his death he ordered the choir stalls for the Church of St Martin in Emmerich and, according to the inscription, they were finished three years after Von Spiegelberg's death.

Von Spiegelberg was an educated man who had friends at the university and who loved books. He was interested in the renewal trends within the church such as the Devotio Moderna: this can be concluded from the facts that he ordered a breviary at the Windesheim monastery in Cologne and took care of the convent of the sisters of the Devotio Moderna in Emmerich. He was also open to humanism, witnessed by the fact that he owned works by Ovid, Cicero and Boccaccio. Furthermore he almost certainly knew Rudulphus Agricola personally and it is sure he arranged for the young Alexander $\mathrm{He}-$ gius to get lessons from him. ${ }^{19}$ In Emmerich he transformed the old chapter-school into a Latin school which became very famous in the sixteenth century. ${ }^{20}$

\section{Description of the Present Day Choir Stalls}

The ensemble as it stands today consist of two rows on different levels (Fig. I). ${ }^{2 I}$ The lower row is placed in front of the upper row and has two parts, each with four seats and misericords. A stair in the middle leads to the upper row and is closed off by a door. This door is crude and undecorated and does not match 


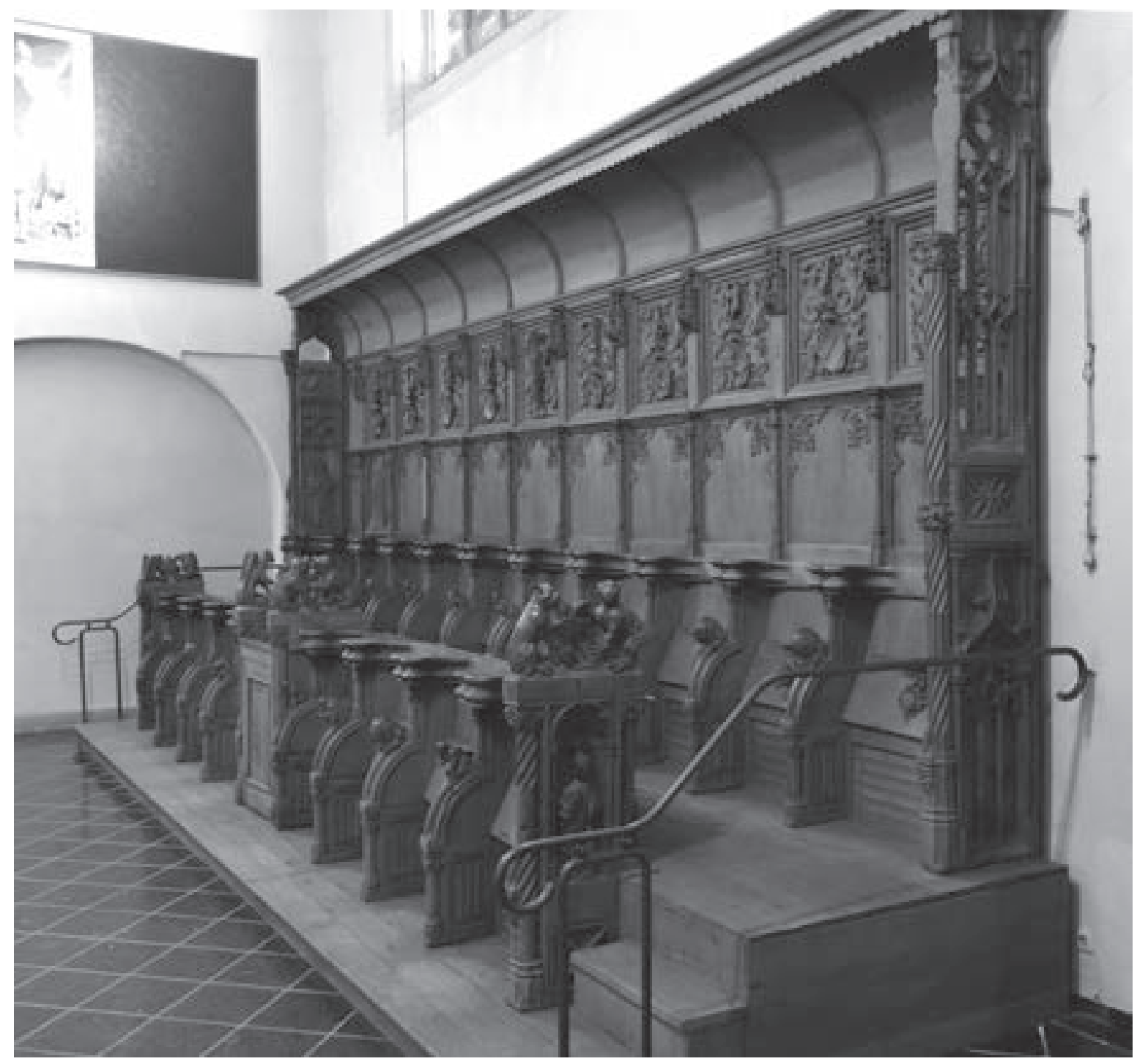

Fig. I. Emmerich, Church of St Martin, view of the choir stalls. Photo by the author.

the choir stalls. It is probably a later addition because the stairs of choir stalls were generally left open.

The two stall ends of the lower row have carvings of two of the church fathers standing in a vaulted niche, on the left, St Augustine, and on the right, St Gregory the Great. The two ends alongside the central stair are decorated with tracery. These four stall ends are topped by pairs of animals. From left to right: two eagles holding a shield bearing the Arma Christi, a griffin fighting with a dragon, two dogs fighting over a bone, and two lionesses, again holding a shield bearing the Arma Christi.
The upper row consists of ten seats also with misericords. The dorsal above the seats has two rows of eleven panels. In the first, lower, row the panels are decorated with tracery and have pillars between them. Here the most obvious and apparent change to the stalls is visible. On the pillars are empty spaces on which once stood little statues, now long gone. The second row consists of nine panels with coats of arms, the middle panel showing a wild man and the one on the far left having no coat of arms, just tracery. From left to right the coats of arms are as follows: Saxony with crancelin, Mark with a fess chequy of three traits, Hoya with two bear's 

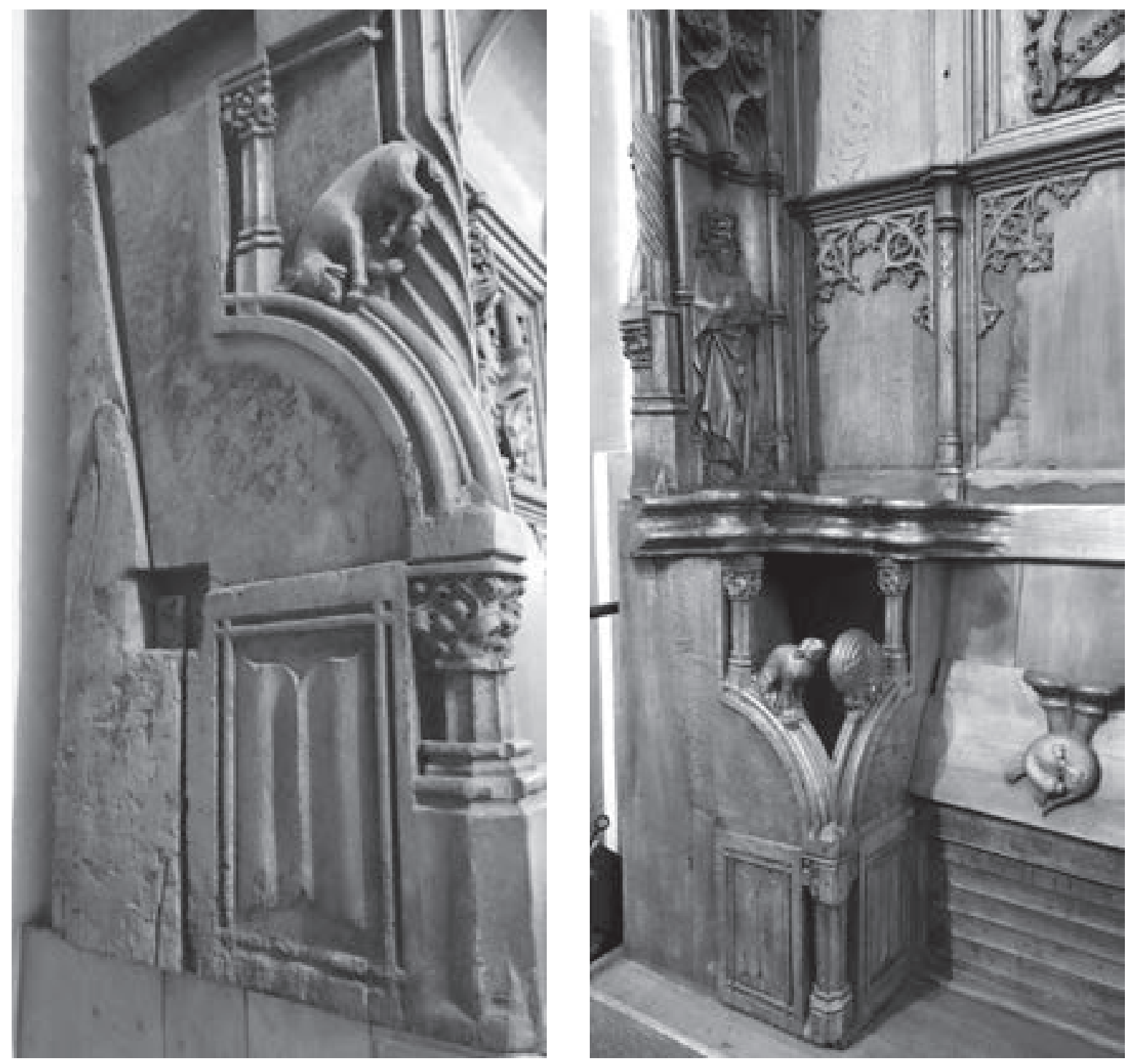

Fig. 2. Stall end of the upper row of the north stalls; photo on the left: exterior of the stall end; photo on the right: interior with the carving of St John the Baptist (above) and the corner junction (below), Emmerich: Church of St Martin. Photo by the author.

paws erased, Lippe with a rose, Spiegelberg with a stag passant, Homburg with a lion rampant, Oldenburg with two bars and the combined coats of arms of Spiegelberg and Emmerich with stag and bucket (Eimer). ${ }^{22}$

The panels are rounded off by a canopy. The row is closed off by two stall ends. The left one is decorated on the inside, with a relief of John the Baptist in a vaulted niche (Fig. I and 2, on the right. In Colour Plate IX, in red indicated with A). At the top of the stall end is a banderol with the year MCCCCLXXXVI. The exterior of the stall end is decorated with a bowing donkey and a panel with a linen fold (Fig. 2, left). This is an unusual decoration for the exterior of a stall end. One would expect tracery, or a saint in a niche, as with the stall ends on the other side (Fig. I). On its outside, the right stall end is decorated with three panels of tracery. The upper part is open and carved on the inside and outside. This stall end is decorated with a pillar on which once stood a statue - now also missing (Fig. I). 
The Events in 1944 and their Consequences

On 7 October 1944 Emmerich was almost completely destroyed by air attacks. The Church of St Martin was hit and burned down. Both sides of the choir stalls were protected against damage by walls erected during the war but when the church caught fire, the burning pulpit spread the fire by way of the stairs attached to the stalls on the south side. This part of the choir stalls was destroyed along with the church, but the north part survived. In the days following the bombing, a part of the remaining stalls, a panel measuring $50 \times 60 \mathrm{~cm}$, was stolen, prompting Carl von Gimborn and employees of the Emmerich factory Probatwerke to dismantle the rest of the the stalls. In the summer of 1945 the parts were stored in a stable on a farm in Hüthum. In 1946 they were returned to Emmerich, but

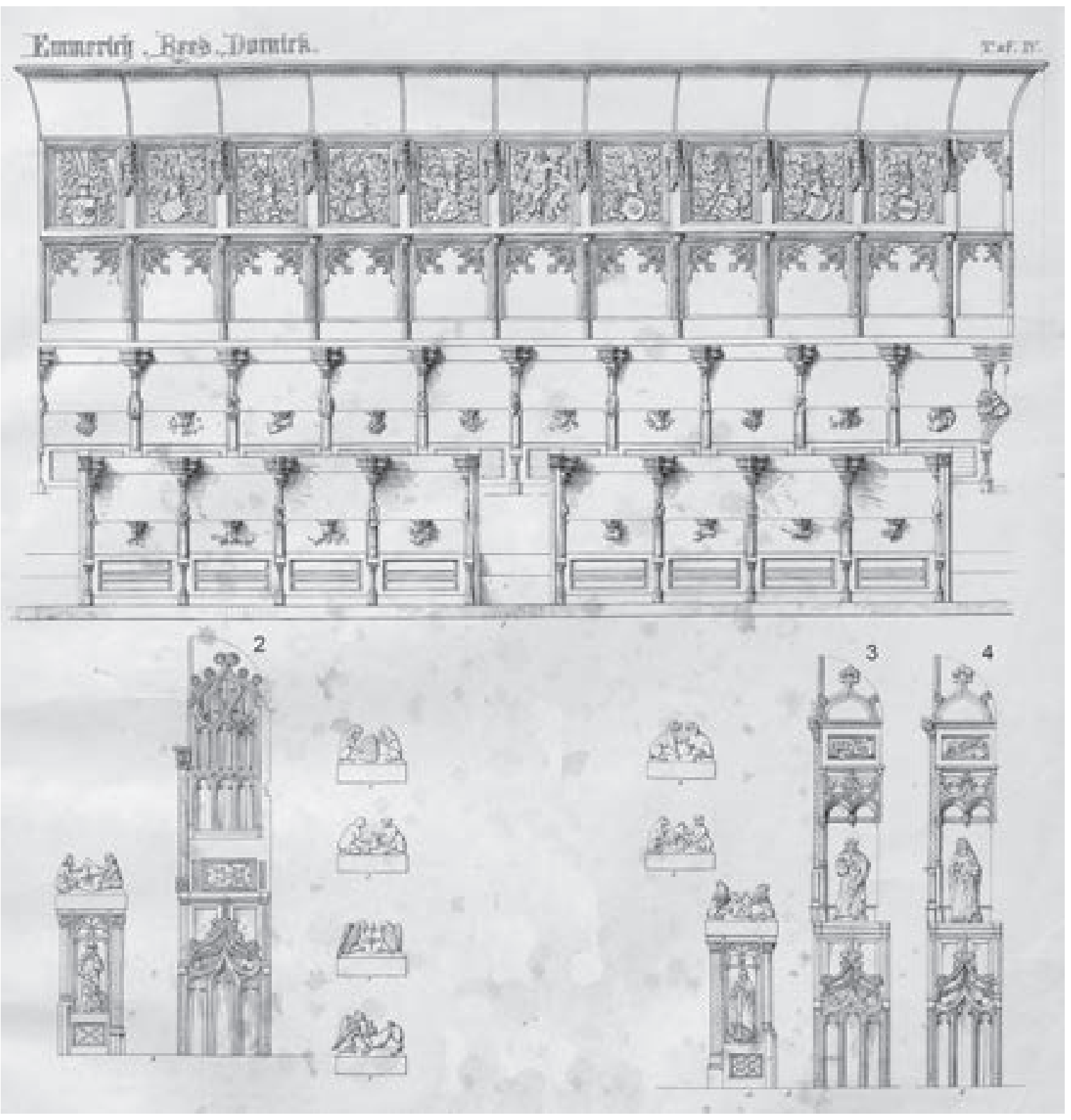

Fig. 3. Adapted illustration of the southern stalls, the stall ends and cappings in the Church of St Martin, Emmerich. From: Aus'm Weerth, Taf. Iv. 


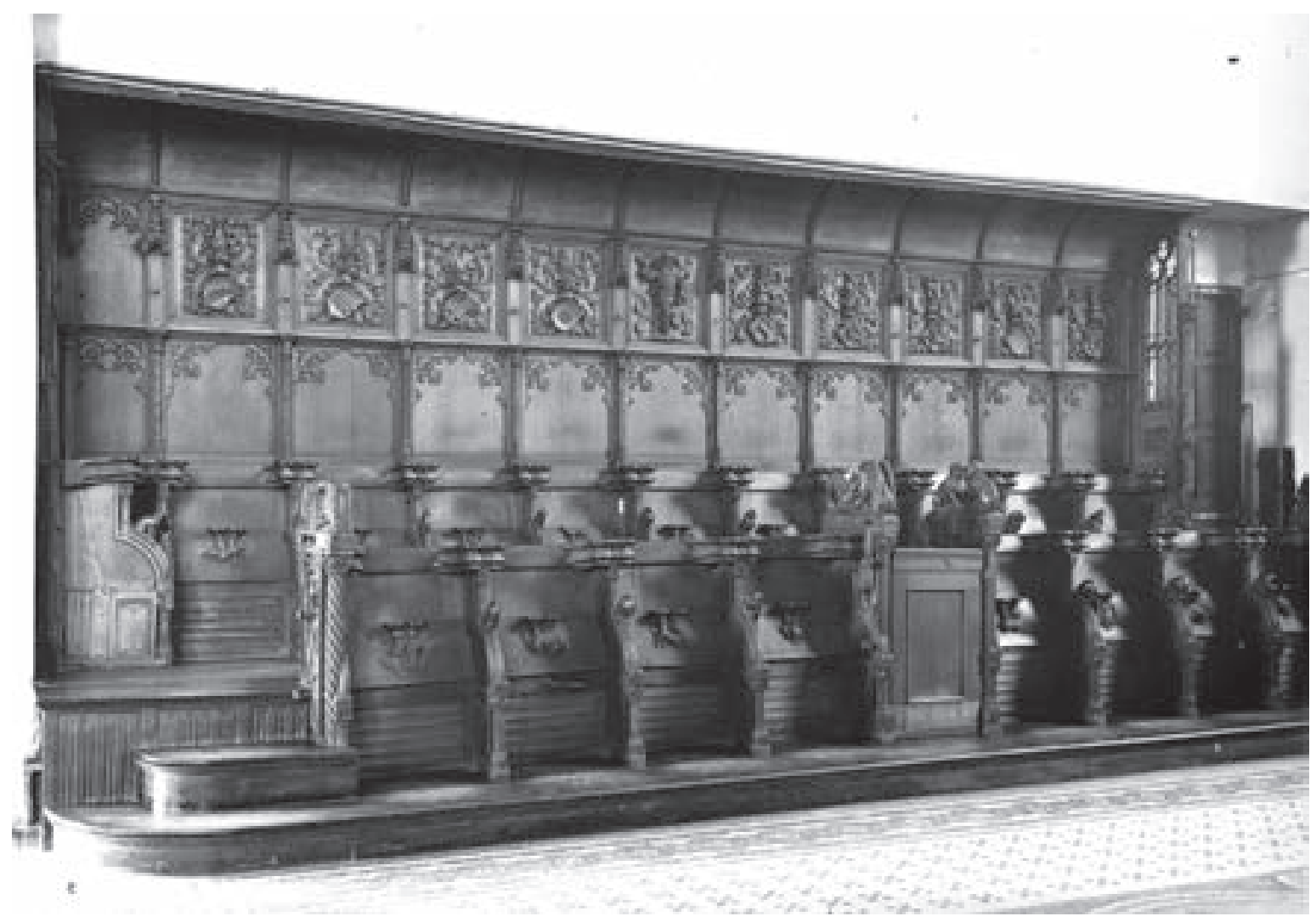

Fig. 4. Northern choir stalls in their niche with, to the right, the door to the northern side chapel, Church of St Martin, Emmerich, 1920. Photo: Stadtarchiv Emmerich am Rhein, 2015/Se.

only to embark on a journey to a variety of locations, among them the ruins of the hospital, the cellars of the Rheinmuseum and the presbytery. Between 1974 and 1977 the choir stalls were restored by the firm of Heinrich Görtzen from Kalkar and the sculptor Wilhelm Mathaii from Kleve. ${ }^{23}$ The stalls as we see them today, state and position, are a result of this restoration

\section{The State before 1944, Going Back to 1828}

After the dissolution of the chapter in I8I I the rood screen became redundant and was demolished in 1828 , creating a direct view from the nave into the choir. The condition of the choir stalls in the period I828-I944 was described and depicted by Aus'm Weerth in 1857 (Fig. 3). ${ }^{24}$ However, the most extensive description was given by Paul Clemen in I892. The burned south side of the stalls was still standing and was mirrored by the one on the north side.
On the south pillar of the crossing, the pulpit, from a later date than the stalls, was attached to the stalls by stairs. The upper rows with the dorsals and the canopies were placed in $60 \mathrm{~cm}$ deep niches that had been especially constructed for them in 1486 (Fig. 4). ${ }^{25}$ These niches also contained the passages to the two chapels on either side of the choir (Colour Plate IX, indicated with $F$ and $G$ ).

The first obvious intervention in this period is the change of the order of the coat of arms on the north side. Kisky described them in 1934 and they are shown on a photograph from before Second World War. ${ }^{26}$ The second and third panel, the coats of arms of Mark and Hoya, were changed round when the parts were re-assembled after 1974. The south side had the same coats of arms in the order Kisky described except for the last one. Instead of the combined coats of arms of Emmerich and Spiegelberg the 
combined coats of arms of Emmerich and Lippe, a bucket and a rose, were depicted.

The coats of arms depicted on the stalls are the Ahnenprobe, or patent of nobility, of Moritz von Spiegelberg in order that all the canons could see who the patron was and what immaculate lineage he had. It is very uncommon to find this feature on choir stalls. In Cappenberg, also, coats of arms are carved on the dorsal but they are the coats of arms of the canons. Only one set of five seats in the chapel of Davensberg has a similar patent of nobility of a single person, namely that of Johann von Büren zu Davensberg with four coats of arms. ${ }^{27}$ The Emmerich stalls are the only one with a double Ahnenprobe of one person.

When one studies the upper stall ends (Fig. 3, nos 2, 3, and 4) in the engraving of Aus'm Weerth, than it has to be noted that something is not right. Judging from the quarter arches at the top of the stall ends where they connect to the canopy, there are three stall ends depicted from one side of the choir stalls and that is not possible (Fig. 3, stall end 2, 3 and 4). It should be two on either side. There is more that is incorrectly depicted. The upper stall ends on the side of the crossing were in a niche, see above (Fig. 4). They were only visible from the inside of the choir stalls and not from the outside (Colour Plate Ix, indicated with B). Yet Aus'm Weerth depicted them as full-length stall ends with panels of tracery beneath the sculptures of the saints. This is a type of stall end, however, that did not exist in the Lower Rhine area. Moreover, it was not impossible to portray the stalls in this way because, during this period, the upper rows with the associated stall ends stood in their niches. ${ }^{28}$ Only the insides of the stall ends were visible. On the north stall end John the Baptist was depicted and on the south stall end Mary Magdalene. Beneath them were no panels with tracery, only seats. ${ }^{29}$ Standing in the choir one saw, on the right above Mary Magdalene, a banderol with ANNO DÑI (Colour Plate IX, in blue indicated with D). On the left above John the Baptist is the banderol with the inscription MCCCCLXXXVI (Colour Plate $\mathrm{IX}$, in red indicated with B).
As mentioned before, the now missing south side was for a great part a mirror image of the north side but there were some differences in the sculpture such as the western upper stall end described above. Also the lower stall ends had different cappings. Starting east and going west: two seated wild men holding a shield with the Arma Christi, two bears with a beehive, eating honey, two monkeys playing with a little dog, and finally two lions, once again holding a shield with the Arma Christi. The two panels placed on lower stall ends had carvings of the other two church fathers standing in vaulted niches, to the east, St Jerome, and to the west, St Ambrose (Fig. 3). Naturally the misericords and elbow carvings had different motifs.

\section{Reconstruction of the Choir Stalls, 1486}

Around 1485 the choir of the Church of St Martin was radically rebuilt in the Gothic style and included a late Gothic rood screen. ${ }^{30}$ This rood screen is depicted on drawings by Jan de Beyer. ${ }^{31}$ The new construction of the choir and the rood screen coincided with, or were probably the reason for Von Spiegelberg ordering the choir stalls that were finished in I486, three years after his death.

During a restoration of the church in I988, over two thousand fragments of the rood screen were found under the church floor. Truus Brandsma and Jos Stöver of Leiden University researched these fragments. They managed to establish how the rood screen had looked. It consisted of five bays with arcades of the following measurements, from north to south: 2.5 , $2.65,2.95,2.65$ and 2.5 metres. ${ }^{32}$ Under the first arcade stood the altar of St Michael, under the third was the altar of St John the Baptist or of the Sacrament, and under the last was the altar of St Barbara. Under the second and the fourth arcade were passages with steps to the choir. ${ }^{33}$ From the fragments of the rood screen it could be concluded that the style of the rood was similar to that of the choir stalls.

The combined facts of a rood screen closing off the choir, the junction in the corner, and a part of a shortened seats at the west end of the north stalls (Fig. 2, right) must lead to the 
conclusion that the shape of the choir stalls was originally different from that in the period after I828. The upper rows must have had an L-shape, positioned along the choir wall and around the corner along the back wall of the first and last bay of the rood screen (Colour Plate Ix, indicated with $\mathrm{B}$ and $\mathrm{D})$. On the side of the choir, the first and last bay measured $52.5 \mathrm{~cm}$. Taking account of the $60 \mathrm{~cm}$ of the niche, the short leg of the L-shaped upper rows (Colour Plate IX, $\mathrm{B}$ and D) must have measured II $2.5 \mathrm{~cm} .{ }^{34}$ From the middle of one arm rest (also called stall capping) to the middle of the other measures $72 \mathrm{~cm}$ which is the width of one seat. The width of the stall end measures $\mathrm{I} 3 \mathrm{~cm}$. Combined, this comes to $85 \mathrm{~cm}$. One can presume that the short leg did not jut out in the passageway to the choir. This leads to the conclusion that there was only space for one seat in the short leg of the L-shape. Whether the short leg was placed against the back of the rood screen, or incorporated in it as the long leg was in the niche in the wall, is impossible to determine.

Research in situ of the stall ends on the remaining lower row show that they were not altered and that they fit to the seats correctly. The conclusion must be drawn that they did not end in an angle of 90 degrees as the lower row of the choir stalls in the Church of the Minorites in Cleves originally did. ${ }^{35}$ The lower rows are as they were always intended to be and are closed off straight by the stall ends as are the lower rows of the stalls in the Cathedral of Erfurt. ${ }^{6}$

Today the lower row is placed in the middle before the upper row (Fig. I). This is also the arrangement as depicted in Aus'm Weerth. ${ }^{37}$ This position is not correct. If the upper rows had an L-shape, there is very little room left between them and the lower rows for a passage with stairs to the upper row. The space would only be $4.5 \mathrm{~cm}$. In a pre-war photograph in Meurer, and also with some difficulty in Figure 4, we can see that the lower row was placed more to the east in alignment with the upper row, as is common in most places. ${ }^{38} \mathrm{~W}$ ith the lower rows in this position there is more room at the west between the lower and upper rows. The only irregularity is that, in this position, the middle entrance is not placed under the middle panel with the wild man, but one panel further to the east.

As mentioned before, the panel with St John the Baptist shows a false armrest with a carving of a bowing donkey on the reverse (Fig. 2, left). Below it is a panel with a linen fold as all the stall standards have on both sides and as the stall ends have on the inside (Fig. I). Above it is a rectangular hole for an arm rest. The measurements of this panel are the same as those of the insides of both stall ends ( $\left.\mathrm{I}_{4} \times 5 \mathrm{I} \mathrm{cm}\right)$. The only conclusion can be that the St John panel was at first the lower part of a stall end with a seat attached to it and the question is to which stall end? The lower rows are not eligible because they are not altered in their construction and are still the same as they were when originally executed and have their associated stall ends. So only the upper stall ends remain as a possibility. There are only two positions were this panel could have been attached to the upper rows. One of the possibilities is on the east side of the south stalls, but that stall end was unaltered and original (Colour Plate IX, indicated with E).39 Which leaves the north end of the short leg of the south upper row (Colour Plate IX, in red indicated with $\mathrm{C}$ ) as the only remaining position. Because this panel had a seat attached to it, it was the lower part of the stall end. The panel with St Mary Magdalene was placed opposite. These positions, the panels of St John the Baptist and St Mary Magdalene in a niche with the inscription above, are more in accordance with the tradition in the Lower Rhine area. Similar panels are placed in the same positon in the stalls in the churches of St Nicolas in Kalkar, of the Minorites in Cleves, of St Martin in Venlo and Reinoldi in Dortmund..$^{40}$ How the upper part of the stall ends originally looked is not known. Probably they had freestanding statues like the stalls in Cleves and Kalkar.

\section{Conclusion}

During the more than five hundred years of its existence only a part of the choir stalls of Emmerich has come down to us. Previous descriptions and research assumed the original choir stalls consisted of thirty-six seats. ${ }^{41}$ Now, be- 
cause of the L-shaped construction of the upper rows along the rood screen, it appears there were thirty-eight seats. Also, as it turns out, not everything belonging to the south stalls was destroyed. The panel of St John the Baptist was originally the lower part of the southern upper stall end.

The present day position and state is not right. Like so many choir stalls, those from Emmerich lost their function when they lost the people that used them. That loss of function, as is the case with all church furniture, is often the beginning of change in the original setting and misplacing of parts. The position ceases to be important and what was once a functional piece of furniture becomes nothing more than a big, unwieldy piece of decoration.

In 1892 Clemen thought he saw the choir stalls as they had been made in I486. If he had all the sources at his disposal he would have known he was wrong. This underlines that even if one is fortunate enough to find a beautiful engraving off the stalls dating from I857, one has to wonder if it is genuine. Once again it is proven that one must not accept sources unquestioningly. Only critical research of the available sources and of the situation in situ can lead us to correct conclusions.

The coat of arms of one family depicted so prominently on the choir stalls is not seen in similar settings elsewhere and it is an obvious mark left by its patron, Moritz von Spiegelberg. His slab in front of the St Anthony altar in the Cathedral of Cologne is long gone but part of his very expensive donation to the Church of St Martin is still standing and is unquestionably a monument in his memory. His choice to depict such an extensive patent of nobility on the choir stalls, not once but twice, must be a sign that he was conscious of who he was: a man on the brink of the Late Middle Ages and the Renaissance. He was interested in de Devotio Moderna and in humanism and yet he ordered a very conservative and elite piece of church furniture, albeit in the most fashionable execution.

8 Truus Brandsma and Jos Stöver, 'Het Doxaal in de Sint-Maartenskerk te Emmerik: van Puinhoop tot Reconstructie', Madoc, 6, 4 (I992), (p. 219).

9 Dehio-Handbuch Nordrhein-Westfalen, I, p. 346.

IO Pfarrarchiv St Martini, Emmerich, B I25: 'In the year of our Lord 1483 the venerable and renowned Lord Moritz Count of Spiegelberg died. He was chaplain and canon of the Holy Church in Cologne furthermore provost in Emmerich and archdeacon of the church of Utrecht. During his lifetime he donated the new skilful and exquisite made seat'.

II Gregor Hövelmann, Moritz Graf von Spiegelberg (1406/1407-1483): Domherr in Köln, Propst in Emmerich, Mäzen und Stifter (Kevelaer: Butzon \& Becker, I987), pp. I7-I 8 .

I2 Ibid., p. 20.

I3 Ibid., p. 23.

I 4 Ibid., p. 25.

I5 Ibid., p. 27.

I6 Ibid., pp. 32-33.

I7 Ibid., pp. 4I-44.

I8 Ibid., pp. 78-83.

I9 Ibid., p. I09. Alexander Hegius or Sander van Heek (c. I439-98) was a humanist and teacher. His most famous pupils were Erasmus and Pope Adrian VI.

20 Lemmens and De Werd, p. I3. 


\section{Willy Piron}

2 I Measured on 2 July 20I5, upper row: width: $5 \mathrm{I} \mathrm{cm}$, length $793 \mathrm{~cm}$, height 3 IO $\mathrm{cm}$; lower row: width $53 \mathrm{~cm}$, length $680 \mathrm{~cm}$, height I52 $\mathrm{cm}$. Clemen gave the following measurements in I892: length $820 \mathrm{~cm}$, height $350 \mathrm{~cm}$.

22 Wilhelm Kisky, 'Die Wappen auf dem Chorgestühl in St Martini in Emmerich', Rheinische Heimatpflege. Zeitschrift für Museumswesen, Denkmalpflege, Archivberatung, Volkstum, Natur- und Landschaftsschutz, 6 (1934), 525-28 (p. 525).

23 Hans Reimann, 'Von der Rettung des Chorgestühls aus St Martini in Emmerich', Kalender für den Kreis Kleve 1976, Ausgabe Nord (1976), I90-92.

24 Ernst Aus'm Weerth, Kunstdenkmäler des Christlichen Mittelalters in den Rheinlanden, Erste Abteilung: Bildnerei (Leipzig: Weigel, I857), pp. 8-Io, Taf. IV.

25 Flintrop, p. 24. According to 'Hochornordwand, Befundskizze Bader, Zustand I937', pp. I38-39, Figs 48-49, the measurements of the niches were approximately: height $470 \mathrm{~cm}$, length $1030 \mathrm{~cm}$, depth $60 \mathrm{~cm}$.

26 Kisky, p. 525. The photograph is in the Stadtarchiv Emmerich and is also published in Heribert Meurer, Das Klever Chorgestühl und Art Beeldsnider (Düsseldorf: Rheinland, I970), Fig. I06.

27 Gerd Dethleffs, 'Die Deutung der Wappen des Cappenberger Chorgestühls', in Das Cappenberger Chorgestühl 1509-1520: Meister Gerlach und die Bildschnitzerwerkstatt der Brabender in Una, ed. by Gerd Dethleffs (Bielefeld: Verlag für Regionalgeschichte, 2009), p. I59.

28 Clemen, p. 4I. Clemen also states that the stalls are installed in the wall ('In die Mauer eingelassen').

29 Ibid., p. 43. n de Beijer, Interior of St Martin in Emmerich, pencil, pen in black and grey and water colour on paper, Haarlem: Teylers Museum, inv. no. v oog; Jan de Beijer, Interior of St Martin in Emmerich, pen in grey and brown, I $45 \times 2$ IO mm, Emmerich: Kath. Pfarrkirche St Martini.

Pfarrarchiv St Martini, Emmerich, B I7. Notebook of the Chapter of St Martin. Schematic drawing of the floor plan of St Martin before I628. Drawing made by Canon Petrus Bögel, dated around I650. The altars are also indicated on the drawing.

34 Measurements were made in situ and on the rebuilding plan by architect Van Aken dating from I949; Flintrop, p. II7, Fig. I9.

35 Meurer, pp. I8-20.

36 Ibid., Fig. 96.

37 Aus'm Weerth, Taf. IV.

38 Ibid., Fig. Io6.

39 Janneke van Golen, 'Het koorgestoelte van de Martinikerk in Emmerich' (unpublished research paper presented at the Bestaria seminar led by dr Martine L. Meuwese, Utrecht University, 2009), pp. I2-I3. Van Golen comes to the conclusion that the panel is attached to stall end indicated with E in Fig. 2.

40 Guido de Werd, Die St Nicolairkirche zu Kalkar, ([n.p.]: DKV, [n.d.]), Fig. 26; Meurer, Figs 2, I04, Io8.

4I Ulrike Spengler-Reffgen, 'Emmerich - St. Martini', in Nordrheinisches Klosterbuch: Lexikon der Stifte und Klöster bis 1815, ed. by Manfred Groten and others, 5 vols (Sieburg: Franz Schmitt, 2009-), II (20I2): Düsseldorf bis Kleve, p. 240. 